\title{
Global currency hierarchy and national policy space: a framework for peripheral economies
}

\author{
Barbara Fritz \\ Professor of Economics, Institute for Latin American Studies, Freie Universität Berlin, Germany \\ Luiz F. de Paula \\ Professor of Economics, Rio de Janeiro State University, Brazil and CNPq researcher \\ Daniela Magalhães Prates \\ Associate Professor of Economics, University of Campinas, Unicamp, Brazil and CNPq researcher
}

\begin{abstract}
In this paper, we develop a Keynesian-structuralist perspective on the origins and implications of the currency bierarchy in the international monetary and financial system. We show that international asymmetry in monetary affairs results in structural implications for peripheral economies. Our main hypothesis is that the international asymmetry related to the currency hierarchy, amplified by financial globalization, imposes major constraints on the adoption of Keynesian policies in these economies. These vary over time and space and depend on certain structures, such as the specific global monetary regime, as well as on domestic institutions and policy variables. For this purpose, we first develop the concept of currency hierarchy and then discuss the structural policy space limitations for the countries at the bottom of this hierarchy. Finally, we provide some brief reflections on the challenges connected to climbing this hierarchy.
\end{abstract}

Keywords: financial globalization, currency hierarchy, Keynesian policies

JEL codes: F3, F4, E6

\section{INTRODUCTION}

Post-Keynesians understand monetary stability as insufficient for achieving the multiple goals regarding growth and employment; therefore, it gives the State an active role in coordinating a series of policies to achieve these goals (for example, Arestis/Sawyer 1998). A closer look at the literature on this topic shows that this approach usually departs from rather general assumptions or applies it mostly to central or advanced economies. In this paper, we ask how we can apply this approach to emerging economies, defined here as peripheral economies that have engaged since the 1990s in the so-called financial globalization, that is, the interpenetration of onshore and offshore financial markets (Chesnais 1996). ${ }^{1}$ We argue that the international asymmetry in monetary affairs, which we define as currency hierarchy $(\mathrm{CH})$, imposes major constraints on the policy space in these countries. These limits vary over time and space depending on the features

1. In this paper, we will use the terms emerging and peripheral synonymously. It is worth mentioning that our definition is similar to the one proposed by Bibow (2009) but is different from the mainstream definition found in The New Palgrave Dictionary of Economics, according to which emerging countries are 'countries ... that are not well established economically and financially, but are making progress in that direction' (Aizenman 2008: 1). 
of the global monetary system and on specific structures such as domestic institutions and policy variables in these countries.

In the field of international political economy, Cohen (1998) prominently elaborates on the concept of the geography of money. He states that there is an incongruence between the geographical space of national boundaries and the acceptance of a currency. While few currencies are used not only within but also beyond national boundaries, the majority of countries, from a global perspective, see their currency space shrunk to an area much smaller than their territory. He calls this a 'currency pyramid', analysing cases from throughout history concerned with different constellations of dominating and dominated currencies and their specific stratification patterns. To explain this pattern, he draws on a political economy analysis that includes power relations such as military strength. He also elaborates on the 'exorbitant privilege': a hegemonic currency which he calls 'top currency' and which enjoys being able to incur domestic currency-denominated debt also at the international level, throwing the potential losses of inflation to the debtors - something other countries, emitting weaker currencies, cannot do. Besides the top currency, other currencies also perform the functions of money at the international level, which he calls patrician and elite currencies. Despite recognizing the role of states in shaping the geography of money, according to Cohen (1998: 117) this 'distinguished elite' of currencies became international currencies through a 'demand driven process of natural selection' that created a hierarchy among moneys (ibid.: 29) and which was fostered by network externalities and economies of scale.

Within standard economics, the so-called 'original sin' approach (Eichengreen/ Hausmann 2005) has gained a lot of attention. Departing from a purely empirical analysis, Eichengreen and Hausmann measure the ability to borrow abroad in one's currency. Their results are telling: more than 90 per cent of all international financial contracts are not denominated in the roughly 150 existing currencies but only in five. $^{2}$ When searching for the causes, they find no significant correlation with policy variables such as debtor behaviour, fiscal profligacy or inflation records. The only relevant link is the size of the country in terms of GDP and global trade weight. They conclude that network effects of large financial networks in terms of currency denomination define the traces of this asymmetric nature of global currency use - an interpretation quite similar to Cohen's Darwinian explanation.

In this paper, we assume a Keynesian-structuralist perspective on the origins and implications of currency hierarchy as was developed originally in the work of Paula et al. (2017). In Section 2, we introduce and develop such concepts, while in Section 3, we discuss the structural limitations of policy space for the countries at the bottom of the $\mathrm{CH}$. We conclude in Section 4 with brief reflections on the challenges involved with climbing this hierarchy.

\section{CURRENCY HIERARCHY}

\subsection{The concept}

The concept of $\mathrm{CH}$ adopted for this paper has been drawn on in at least two different strands of literature. First, Keynes, in both the Treatise on Money and in his preparatory

2. Flandreau/Sussmann (2005) show that Latin American countries, from the beginning of the creation of domestic currencies together with political independence, were confronted with the fact that the bonds they emitted at the international market contained gold clauses, giving them the characteristics of foreign-exchange-denominated debt. This is what Eichengreen/Hausmann (2005) label the 'original sin': a country's inability to borrow abroad in its own currency. 
works for the Bretton Woods Conference (Keynes 1930; 1944) stressed the hierarchical feature of an international monetary system based on a key currency. Indeed, the central aim of his proposal at this conference, the creation of the International Clearing Union and the multilateral currency the Bancor, was to eliminate that feature. However, he had no specific focus relating to peripheral economies. Keynes's seminal idea, in turn, has been developed independently by two groups of Keynesians whose approaches share many ideas, such as the German Monetary Keynesians (for example, Nitsch 1999; Riese 2004), inspired by the trajectory of the Deutsche mark in the postwar period; and the economists of the so-called Campinas School (for example, Belluzzo/Carneiro 2004), motivated by the historical external vulnerability of the Latin American economies.

Second, the Latin American structuralist approach, especially its analysis of global economic asymmetries, provides useful insights into the international monetary asymmetry. In the immediate postwar period, structuralist economists in Latin America, especially at the UN Economic Commission for Latin America and the Caribbean (ECLAC), brought forward the figure of a 'centre-periphery' relationship, which was inherently structured around the division between producers of commodities and of manufactured goods that are perpetuated through global free trade (Prebisch 1949). Ocampo (2001) uses the same figure of the centre-periphery relationship but translates it from the world of trade into the sphere of finance. He argues that the end of the global monetary and financial order of Bretton Woods brought with it a shift of relevance from trade to finance. He assumes that we have the same kind of asymmetric relations between centre and periphery countries reflected in financial asymmetries.

More recently, post-Keynesian authors (for example, Andrade/Prates 2013; Paula et al. 2017) have joined this structuralist perspective to the Keynesian approach on $\mathrm{CH}$, pointing out that in the post-Bretton Woods setting, the asymmetries of the international monetary and financial system have gained importance, overlapping with the technological and productive ones (emphasized by classic structuralism). Hence, they support that the $\mathrm{CH}$ is featured not only by the existence of a key currency at the top but also by asymmetries between centre and peripheral currencies. These asymmetries are reflected in differing shares of currencies in their global use as units of account, means of payment and/or reserve of value.

The $\mathrm{CH}$ after the launch of the euro is depicted by De Conti/Prates (2016). Based on a set of databases, their research provides indicators of the different uses of currencies at the global level. Table 1 shows the use of the currencies as a means of payment as a representative indicator for the current profile of this hierarchy. As we can see in the table, the US dollar maintains its position as the key currency in 2001-2016, followed by the euro and the yen. In 2016, the four major currencies accounted for 76.6 per cent of the total.

The starting point of the Keynesian-structuralist perspective followed here is chapter 17 of The General Theory (Keynes 1936). Here, Keynes establishes the equation of the total return of specific assets - these can be money but also other assets - defined by the sum of four specific attributes, which are: $a$, the expected appreciation of this asset; $q$, the expected quasi-rent; $c$, the transaction or carrying cost of this asset; and $l$, the very Keynesian concept of the liquidity premium which is the non-pecuniary return of holding money or an asset to tackle all issues of uncertainty.

As detailed by Paula et al. (2017), when applying this equation on the international level, currencies are hierarchically positioned according to their degree of liquidity $l$, which relates to their ability to perform the three functions of money internationally (see Figure 1). Therefore, when we apply Keynes's attributes to the different currencies, the key currency, currently the US fiduciary and flexible dollar, is placed at the top of the hierarchy as it has the highest $l$. The currencies issued by the other centre countries, labelled the Northern currencies, are in intermediate positions as they are also liquid currencies, yet with smaller $l$ than the key currency. At the opposite end are the currencies 
Table 1 Currency distribution of global foreign-exchange market turnover, selected currencies on a net-net basis, percentage shares of average daily turnover in April 2016

\begin{tabular}{lrrrrrr}
\hline Currency & 2001 & 2004 & 2007 & 2010 & 2013 & 2016 \\
\hline US dollar & 89.9 & 88 & 85.6 & 84.9 & 87.0 & 87.6 \\
Euro & 37.9 & 37.4 & 37.0 & 39.1 & 33.4 & 31.3 \\
Yen & 23.5 & 20.8 & 17.2 & 19.0 & 23.0 & 21.6 \\
Pound sterling & 13.0 & 16.5 & 14.9 & 12.9 & 11.8 & 12.8 \\
Australian dollar & 4.3 & 6.0 & 6.6 & 7.6 & 8.6 & 6.9 \\
Canadian dollar & 4.5 & 4.2 & 4.3 & 5.3 & 4.6 & 5.1 \\
Swiss franc & 6.0 & 6.0 & 6.8 & 6.3 & 5.2 & 4.8 \\
Chinese yuan & 0.0 & 0.1 & 0.5 & 0.9 & 2.2 & 4.0 \\
Mexican peso & 0.8 & 1.1 & 1.3 & 1.3 & 2.5 & 2.2 \\
Russian rouble & 0.3 & 0.6 & 0.7 & 0.9 & 1.6 & 1.1 \\
Indian rupee & 0.2 & 0.3 & 0.7 & 1.0 & 1.0 & 1.1 \\
South African rand & 0.9 & 0.7 & 0.9 & 0.7 & 1.1 & 1.0 \\
Brazilian real & 0.5 & 0.3 & 0.4 & 0.7 & 1.1 & 1.0 \\
Other currencies & 6.9 & 6.9 & 8.2 & 5.4 & 2.5 & 3.3 \\
Total & 200 & 200 & 200 & 200 & 200 & 200 \\
\hline
\end{tabular}

Note: a. The sum is 200 per cent as each international financial transaction involves two currencies. Source: Di Conti/Prates (2016: 11), based on BIS Triennial central-bank survey of foreign-exchange and derivatives market activity in 2016.

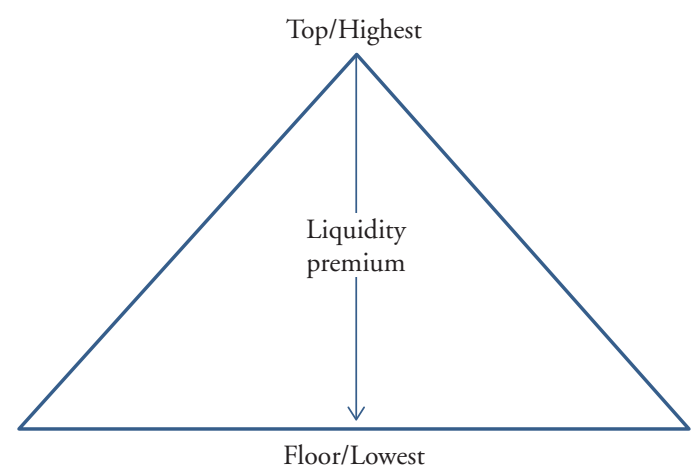

Source: Paula et al. (2017).

\section{Figure 1 Currency hierarchy}

issued by the peripheral countries, called here the Southern currencies, whose liquidity premium is lower than that of the key currency and of those in the middle, hence $l_{s}<$ $l_{n}(n=$ North; $s=$ South). Therefore, $l$ is a structural variable which could be influenced by policy variables only in the long term. ${ }^{3}$

3. Kaltenbrunner (2015) extends existing post-Keynesian analyses of the international currency hierarchy with a Minskyan approach. She also applies Keynes's equation of the total return of assets to different currencies but focuses on exchange-rate determination (as per Andrade/Prates 2013), while our focus is the expected return of assets denominated in a specific currency. Moreover, to the contrary of our approach, she considers that the attribute $c$ is negligible and that the attribute $l$ has a structural dimension but also depends on the net foreign currency debtor positions (mainly, external debt). 
Regarding the other attributes, $a$ turns into the expected exchange rate, which in the postBretton Woods context is determined not by fundamentals but by short-term gains; $q$ turns into the short-term interest rate of the different currencies; and $c$ turns into the degree of financial openness of each country. Thus, to compensate for their lower liquidity premium, southern currencies have to offer a higher $q$ (which is a policy variable) in order to try to achieve a higher $a$ (currency appreciation), creating conditions which are attractive for international investors and/or which reduce $c$, that is, the obstacles for capital inflows (or capital outflows) with the withdrawal of capital account regulation (see Section 3). Only under these conditions can asset markets reach an equilibrium:

$$
a_{n}+q_{n}-c_{n}+l_{n}=a_{s}+q_{s}-c_{s}+l_{s} .
$$

Therefore, monetary returns of the assets denominated in a Southern currency have to compensate their lower liquidity premium relative to that of the key currency (and the other Northern currencies) in order to induce foreign investors - and, in the case of an open capital account for capital outflows, also domestic investors - to demand such assets:

$$
l_{n}-l_{s}=\left(a_{s}+q_{s}-c_{s}\right)-\left(a_{n}+q_{n}-c_{n}\right) .
$$

\subsection{Structural feature with changes over time}

The currency hierarchy has been a fundamental feature of the international monetary systems that have succeeded at least since the sterling-Gold Standard, as pointed out by Keynes $(1930 ; 1944)$. However, this hierarchy has revealed itself as even more deleterious after the emergence of the so-called financial globalization.

Historically, two main characteristics shape the profile of the international monetary and financial system: (i) the global exchange rate regime, which can range from fully flexible exchange rates to a system of fixed rates; and (ii) international capital account regulation, which is depicted in a continuum ranging from highly regulated to unregulated trans-border financial flows. ${ }^{4}$ The combination of these two variables results in a system of four quadrants. Technically, we can distinguish two rather stable arrangements, where one dimension is unregulated and the other regulated: one extreme stable, where both dimensions are regulated, and, on the opposite side, one highly unstable combination of both unregulated dimensions.

This allows us to structure the last 100 years, during which the Bretton Woods period appears as an extremely stable global regime which provided highly stable global conditions also for peripheral countries. The fixed but adjustable exchange-rate regime very much narrowed the scope of the expected exchange change variation, $a$, and the global regime of strong capital account restrictions impeded the use of $c$ as an instrument to increase demand for one's own currency. The interplay of these factors contributed to increasing the policy space (that is, the autonomy of macroeconomic policy) in these countries, which is structurally lower than in centre countries exactly because of the low liquidity premium of their currencies. ${ }^{5}$ Another consequence of those advantageous conditions for peripheral countries was the absence of banking and financial crises in this period, as Reinhart/Rogoff (2009) show.

4. One may add as a third dimension the existence of a specific key or hegemonic currency versus a multi-currency standard.

5. For more details on the relationship between liquidity premium and policy space, see Paula et al. (2017). 


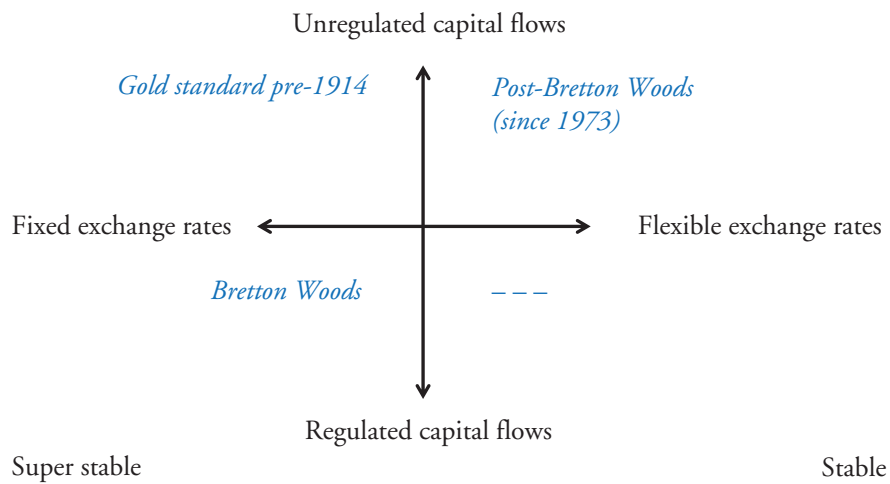

Source: Authors' own compilation, adapted from Herr (2001: 178).

\section{Figure 2 Global monetary regimes}

To the contrary, the post-Bretton Woods period - defined by the fiduciary dollar as the key currency, floating exchange rates and financial globalization - is extremely unstable, even compared to the prewar Gold Standard period (see Figure 2). Especially since the 1990 s, when an increasing number of peripheral countries turned themselves into emerging economies by opening their capital accounts, the volume and volatility of global capital flows increased, fostering the exchange-rate volatility $a$ and the frequency and depth of financial crises (see also Ghosh 2018, in this special issue). Besides the higher vulnerability to these crises, emerging economies have also faced a lower policy space than in the Bretton Woods regime as is detailed in the next section. In other words, the international monetary and financial system has become even more asymmetric with greater differences between the degree of policy space of the key-currency issuer, on the one hand, and Northern currency and Southern currency issuers, on the other hand. In the words of Ocampo (2001), the macroeconomic asymmetry has increased.

\section{LIMITS OF POLICY SPACE AT THE CH BOTTOM}

In this section, we discuss the limits on exchange rate, monetary and fiscal policies of peripheral emerging countries that stem from the position of their currencies at the lower end of the currency hierarchy. We argue that financial globalization increases constraints on the adoption of Keynesian policies for emerging economies. Conventional wisdom brings forward the idea that financial globalization enforces market discipline, stimulating more consistent macroeconomic policies. The argument put forward is that market forces, represented by rational foreign investors, could penalize inconsistent fiscal and monetary policies and the lack of property rights guarantees (Fischer 1998; Rogoff et al. 2004). Conversely, we sustain that macroeconomic instability can be the endogenous result of the operation of conventional policies under the conditions of monetary and financial asymmetries in the absence of some sort of defensive mechanisms, such as capital account regulation, foreign reserve accumulation, etc. Consequently, 'the punishment through capital markets can be so disastrous 
with irreversible collateral damages, that it turns to be destructive' (Priewe 2008: 44-45, emphasis in original).

This is because one of the main consequences of these asymmetries in the post-Bretton Woods setting is the volatility of capital flows. As the post-Keynesian literature (Harvey 2009; Schulmeister 1988) has highlighted, short-term capital flows and expectations about differentials of yields and/or liquidity constitute the key determinants of exchange rates. Yet, in the case of Southern currencies, such volatility is higher than for Northern currencies, and these flows are even more sensitive to the monetary policy in the centre (see Griffith-Jones 1998). As exchange rates tend to be more volatile, more frequent centralbank interventions are required (Ramos 2016), which, in turn, reinforce the interaction between the exchange rate and the policy rate. Therefore, we assume that the loss of monetary autonomy in a context of free capital mobility is greater.

This higher exchange-rate volatility hampers growth and increases financial fragility and inflation (Flassbeck 2001). When the global financial cycle reverses, due to monetary policy changes in the centre or because liquidity preference increases, emerging financial assets are the first victims of the global investors' flight to quality as they cannot provide a safe haven under uncertainty on a global scale. In this setting, the liquidity premium $l$ and the expected appreciation $a$ come into play since it is mainly by means of their assessment that agents in currency markets make decisions regarding which assets to demand. If investors leave these countries swiftly, this will most likely result in a currency depreciation. To prevent this, local policy-makers are under pressure to raise the interest rate, with the aim of increasing $q$ and $a$ as well as to deepen financial openness - namely, by removing capital account regulation to reduce $c$. If this policy is successful, $(a+q-c)$ will increase to compensate the lower liquidity premium $l$ (Andrade/Prates 2013). As Grabel (1996: 1763) stresses, the movement of portfolio investment induced by these policies produces two harmful outcomes: 'the exacerbation of constraints on policy autonomy; and the increased vulnerability of the economy to risk, financial volatility and crisis'.

On the other hand, in boom periods of capital flows, when the appetite for risk is higher, emerging assets become objects of desire on the part of global investors because of an expected appreciation (increase in $a$ ) of their respective currencies. This, together with a positive interest-rate differential, compensates for their reduced liquidity premium $l$. Yet higher capital inflows, in the form of increased external debt and/or a higher portfolio investment, put pressure on the appreciation of the domestic currency, causing boombust cycles of credit and capital inflows and the subsequent need to further increase the interest rate.

What also contributes to higher interest rates in peripheral emerging countries is that, in comparison with the centre countries, some traditional transmission channels of monetary policy do not work well. First, the credit channel is less effective due to the smaller credit ratio of private sector to GDP. Second, the low development of capital market makes domestic expenditure less sensitive to the wealth effect. Third, higher exchange-rate volatility makes inflation higher. Additionally, studies have shown that exchange-rate passthrough has tended to be stronger in such economies. ${ }^{6}$ As exchange-rate movements play a more prominent role here than in more advanced economies, central banks rely often on interest-rate changes to stem exchange-rate volatility.

6. The main reason is that income is negatively and significantly correlated with pass-through as lower income economies have a larger portion of traded goods in the household consumption basket. See Mohanty/Scatigna (2005). 
These specificities of monetary policy in peripheral emerging countries make the implementation of inflation-targeting regimes (ITRs), adopted by an increasing number of these countries since the beginning of the 1990s, even harder than in advanced ones. Indeed, even the standard literature recognizes that emerging countries face particular challenges when they put in place ITRs due to (i) their higher pass-through (see above); (ii) the greater difficulty in forecasting inflation, because shocks are larger and have stronger effects, meaning that the productive diversification is lower and domestic financial markets are shallower; (iii) their external liabilities are overwhelmingly denominated in external currency (original sin) creating a problem of 'fear of floating'; and (iv) many emerging economies have a credibility problem regarding monetary policy, which is at least partially interdependent with these structural features (Eichengreen 2002).

Yet there is an additional specific feature of ITRs which applies under the condition of an open capital account that further complicates the achievement of a competitive and stable exchange rate, thus perpetuating the problem of the low position in the currency hierarchy. The problem is that a nominal appreciation of the currency is much more credible for a central bank committed to inflation targeting than depreciation due to the negative effect of the latter on inflation through its pass-through effect. Indeed, empirical evidence shows that in many emerging countries that adopt ITRs, central banks make use of deliberate asymmetric policy with respect to the exchange rate as they avoid sharp currency depreciation and tend to tolerate currency appreciation as it contributes to the achievement of the inflation targets. Thus, under ITRs, actors in the currency market internalize the expectation that the central bank has an inclination towards currency appreciation, giving it highly asymmetric power to influence the exchange rate and creating an upward trend which may further exacerbate exchange-rate volatility and related boom-bust cycles (Kaltenbrunner 2011).

The very concept of currency hierarchy requires a specific set of policies to compensate the difference between the liquidity premiums of currencies. One option could be to adopt capital controls to drive a wedge between onshore and offshore interest rates in order to provide monetary authorities with some policy autonomy to increase or reduce interest rates. Yet this kind of policy is difficult to implement successfully when there are devaluation expectations attached to this peripheral currency. When currency devaluation expectations are predominant, market actors will urgently seek to circumvent outflow controls in order to prevent future income and wealth losses.

The other option is the orthodox prescription of increasing the interest rate to compensate for the lower liquidity premium. This makes domestic investment and growth dependent on capital inflows. This growth-cum-external-debt may, in the best case, increase domestic investment; however, it does also cause an appreciation of the domestic currency, which, in turn, decreases international competitiveness. This can make the growth process unsustainable in the medium term, as growing external vulnerability creates devaluation expectations and will likely, at some point, cause the reversal of capital flows which may cause a financial crisis in the emerging economy. ${ }^{7}$ Also, fiscal policy is frequently managed in a pro-cyclical way since the abrupt reversion of capital inflows surges, even if caused by exogenous factors, will require fiscal tightening to compensate the negative effects of currency depreciation on the fiscal balance as well as to inspire global investors' confidence. Indeed, one of the consequences of capital account liberalization in a world of monetary and financial asymmetries is that 'fundamentals' of peripheral emerging economies are

7. Kaltenbrunner (2015) points out that in emerging economies, short-term foreign liabilities exert a latent depreciating pressure on the domestic currency that severely restricts their currencies' ability to become international media of contractual settlement and stores of value. 
subject to the assessment of foreign investors and rating agencies. Regardless of whether the concerns about the fiscal stance are well founded, financial market actors' reactions cannot be shrugged off (Neville 2012). Consequently, fiscal policy may have to be modified to reduce the fears of those markets, putting a limit on the implementation of counter-cyclical fiscal policies in peripheral emerging economies. Furthermore, the absence of an effective welfare state in most emerging countries that could work as a safety net reduces the effect of the automatic fiscal stabilizers that act as counter-cyclical policies in the downturn.

Another concern is the impact of the high volatility of capital flows in fiscal revenues. The boom-and-bust movements of foreign finance result in pro-cyclical movements of GDP and, consequently, high oscillation of fiscal revenues that reduce sharply in the downturn. For all these reasons, the scope for implementation of counter-cyclical fiscal policies decreases a great deal more in such economies compared to centre economies. Moreover, even during the boom phase of the capital flows cycle, the fiscal stance generally is affected adversely. As peripheral emerging economies have to implement foreign reserve accumulation as a defensive and precautionary response to enhance their capacity of restraining speculative attacks in times of capital flows reversals, the need to sterilize the monetary impact of that policy (to counter the downward pressures on the policy rate) results in fiscal costs due the high interest-rate differentials.

\section{CONCLUSION: CHALLENGES FOR CLIMBING THE LADDER}

Currency hierarchy is a structural feature of the international monetary and financial system that could hamper the adoption of pro-growth and redistributive policies as the economies at the bottom of the hierarchy face a lower degree of policy space. This is relevant for all kinds of analysis that are focused on economic policies and outcomes in these countries.

How can countries climb the ladder and overcome these structural constraints? From our theoretical perspective, to increase the liquidity premium of a currency, it is first and foremost necessary to reduce exchange-rate volatility. By doing this, domestic monetary policy can be relieved from countering devaluation expectations. Preventing exchange-rate overvaluation makes it easier to increase international competitiveness and diversify the export structure, thus reducing the destabilizing potential of typically large price swings of commodities. For this endeavour, the currency needs to be protected from the international liquidity cycle with its enormous up- and downswings. Capital account regulation thus becomes a key element of such a strategy and works to also drive a wedge between onshore and offshore interest rates in order to provide monetary authorities with greater policy autonomy for domestic purposes. Financial development, in terms of institutional building and provision of public credit in domestic currency at affordable interest rates, might well complement this exchange-rate strategy by limiting the exposure to foreign currency-denominated debt.

Within this prioritizing of exchange-rate stabilization at a competitive level, together with inflation stabilization, an ITR is not suitable for this strategy as it does not allow for the double target of stabilizing the price level and the exchange rate at the same time. Moreover, it also constrains the leeway for expansive fiscal policy over the cycle because within this framework, this policy is subordinate to the monetary policy. Therefore, in order to reach this double target, macroeconomic policies should be carefully coordinated, giving priority to instruments that stabilize domestic demand over the cycle (see Paula et al. 2017). Yet, the relative change of the position within this hierarchy is not a short-term, easy goal that would be met through the adoption of a standardized set of policies. First, it is a rather long-term and difficult endeavour to increase the liquidity premium, and it 
involves a high degree of inertia. Second, the specific global monetary regime can provide a certain level of leeway for reducing this structural asymmetry. As argued, the current constellation of uncoordinated exchange rates with the wide liberalization of capital flows further exacerbates the peripheral position of emerging market economies. Third, both the level of vulnerability to external shocks (such as the level of net external debt, the moment of the liquidity cycle and the level and capabilities of productive diversification) and specific institutional features of domestic institutions (such as wage formation or tax collection) determine the capacity of a country to pursue such a strategy.

Finally, yet importantly, this cannot be a universal strategy to help all countries climb the ladder. Achieving a current-account surplus is relevant for reducing vulnerability to external shocks. Yet, on the global level, current-account surpluses of some countries require deficits for other countries; climbing up the currency ladder requires that others might be climbing down, as global investors will always restrict their demand to a selected group of a few currencies due to the hierarchy being a structural feature of a global monetary economy. So, this means that such a strategy cannot be pursued by all peripheral countries at once.

\section{REFERENCES}

Aizenman, J. (2008): Emerging markets, in: Blume, L.E., Durlauf, S.N. (eds), The New Palgrave Dictionary of Economics, Basingstoke, UK: Palgrave Macmillan, 3729-3734.

Andrade, R., Prates, D.M. (2013): Exchange rate dynamics in a peripheral monetary economy, in: Journal of Post Keynesian Economics, 35, 399-416.

Arestis, P., Sawyer, M. (1998): Keynesian economic policies for the new millennium, in: Economic Journal, 108, 181-195.

Belluzzo, L.G., Carneiro, R. (2004): O mito da conversibilidade, in: Revista de Economia Política, 24(2), 218-222.

Bibow, J. (2009): The international monetary (non-)order and the global capital flows paradox, in: Hein, E., Niechoj, T., Spahn, P., Truger, A. (eds), Finance-led Capitalism? Macroeconomic Effects of Changes in the Financial Sector, Marburg: Metropolis Verlag, 219-248.

Chesnais, F. (1996): Introduction Générale, in: Chesnais, F. (ed.), La Mondialisation Financière: Genèse, Coût et Enjeux, Paris: Syros, 11-33.

Cohen, B.J. (1998): The Geography of Money, Ithaca, NY: Cornell University Press.

De Conti, B., Prates, D.M. (2016): The international monetary system hierarchy: current configuration and determinants, The 28th Annual EAEPE Conference Manchester, UK, 3-5 November.

Eichengreen, B. (2002): Can emerging markets float? Should they inflation target? Banco Central do Brasil Working Paper no 36, February.

Eichengreen, B., Hausmann, R. (eds) (2005): Other People's Money: Debt Denomination and Financial Instability in Emerging Market Economies, Chicago: University of Chicago Press.

Fischer, S. (1998): Capital account liberalization and the role of the IMF, Essays in International Finance no 207, Princeton, NJ.

Flandreau, M., Sussmann, N. (2005): Old sins: exchange clauses and European foreign lending in the nineteenth century, in: Eichengreen, B., Hausmann, R. (eds), Other People's Money: Debt Denomination and Financial Instability in Emerging Market Economies, Chicago: University of Chicago Press, 154-189.

Flassbeck, H. (2001): The exchange rate: market price or economic policy tool, UNCTAD Discussion Paper no 149, November.

Ghosh, J. (2018): Global instability and the development project: is the 21 st century different?, in: European Journal of Economics and Economic Policies, 15(2), 193-207.

Grabel, I. (1996): Marketing the third world: the contradictions of portfolio investment in the global economy, in: World Development, 24(11), 1761-1776.

Griffith-Jones, S. (1998): Global Capital Flows: Should They be Regulated? New York: Macmillan and St. Martin's Press. 
Harvey, J.T. (2009): Currencies, Capital Flows and Crises: A Post Keynesian Analysis of Exchange Rate Determination, London: Routledge.

Herr, H. (2001): Weltwährungssysteme im Rückblick - Lehren für die Zukunft, in: Heise, H. (ed.), Neue Weltwährungsarchitektur, Marburg: Metropolis Verlag, 161-200.

Kaltenbrunner, A. (2011): Currency internationalization and exchange rate dynamics in emerging markets: a post-Keynesian analysis of Brazil, $\mathrm{PhD}$ dissertation, School of Oriental and African Studies (SOAS), University of London.

Kaltenbrunner, A. (2015): A post Keynesian framework of exchange rate determination: a Minskyan approach, in: Journal of Post Keynesian Economics, 38, 426-448.

Keynes, J.M. (1930 [2013]): The Treatise on Money, II: The Applied Theory of Money. The Collected Writings of John Maynard Keynes, vol. VI, Cambridge, UK: Cambridge University Press, 189-367.

Keynes, J.M. (1936): The General Theory of Employment, Interest and Money, London: Macmillan.

Keynes, J.M. (1944 [2013]): Activities 1941-46: The Clearing Union. The Collected Writings of John Maynard Keynes, vol. XXV, Cambridge, UK: Cambridge University Press, 1-238.

Mohanty, M., Scatigna, M. (2005): Has globalization reduced monetary policy independence? BIS Papers no 23.

Neville, J.W. (2012): Fiscal policy, in: Arestis, P., Sawyer, M. (eds), The Elgar Companion to Post Keynesian Economics, Cheltenham, UK and Northampton, MA: Edward Elgar Publishing, 224-229.

Nitsch, M. (1999): Vom Nutzen des monetär-keynesianischen Ansatzes für Entwicklungstheorie und -politik, in: Schubert, R. (ed.), Neue Wachstums- und Außenhandelstheorie - Implikationen für die Entwicklungstheorie und -politik (Schriften des Vereins für Sozialpolitik, Neue Folge Bd. 269), Berlin: Duncker \& Humblot, 183-214.

Ocampo, J.A. (2001): International asymmetries and the design of the international financial system, CEPAL Serie Temas de Coyuntura no 15, Santiago de Chile: CEPAL.

Paula, L.F., Fritz, B., Prates, D.M. (2017): Keynes at the periphery: currency hierarchy and challenges for economic policy in emerging economies, in: Journal of Post Keynesian Economics, 40(2), 183-202.

Prebisch, R. (1949): The Economic Development of Latin America and its Principal Problems, New York: United Nations Department of Economic Affairs.

Priewe, J. (2008): Capital account management or laissez-faire of capital flows in developing countries, in: Arestis, P., Paula, L.F. (eds), Financial Liberalization and Economic Performance in Emerging Countries, London: Palgrave Macmillan, 26-51.

Ramos, R. (2016): Financialization and its implications on the determination of exchange rates of emerging market economies, PhD dissertation, University of Paris 13 and University of Campinas.

Reinhart, C., Rogoff, K. (2009): This Time is Different: Eight Centuries of Financial Folly, Princeton, NJ: Princeton University Press.

Riese, H. (2004): Development strategy and economic theory: comments on a neglected topic, in: Hölscher, J., Tomann, H. (eds), Money, Development and Economic Transformation: Selected Essays, London: Palgrave, 84-113.

Rogoff, K., Kose, A., Prasad, E., Wei, S.-J. (2004): Effects of financial globalization on developing countries: some empirical evidence, IMF Occasional Papers 220, May.

Schulmeister, S. (1988): Currency speculation and dollar fluctuations, in: Banca Nazionale Del Lavoro Quarterly Review, December, 343-366. 